\title{
Immunodominant carbohydrate determinants in the multicellular stages of Dictyostelium discoideum
}

\author{
Alan Champion, Andrew A. Gooley, Michelle Callaghan, $†$ M. Ines Carrin, $\ddagger$ \\ R. L. BeRnstein, § Elizabeth SMith and Keith L. Williams*
}

School of Biological Sciences, Macquarie University, Sydney, NSW 2109, Australia

(Received 3 April 1991; revised 5 July 1991; accepted 15 July 1991)

\begin{abstract}
Two families of glycoprotein are defined in Dictyostelium discoideum by the presence of different glycoconjugates, both of which are highly immunogenic in mice. The previously described monoclonal antibodies MUD50 and MUD62 recognize the glycoconjugates and identify the respective glycoprotein families. Both types of glycosylation occur on vegetative and developmentally regulated glycoproteins. The immunodominant components of both families are reportedly $O$-linked sugars, but Western blots do not identify any glycoprotein that has both $O$-glycans, suggesting that there are two independently processed types of $O$-linked glycosylation in $D$. discoideum. The synthesis of the two $\mathbf{O}$-glycan families is affected by glycosylation-defective mutations. Strains with a mutation at the modB locus lack one of these glycosylation types (that recognized by MUD50) and this mutation alters the size of two minor glycoproteins in the second family. Two new mutants, HU2470 (mod-352) and HU2471 (mod-353), lack the epitope recognized by MUD62. The two mutations map to different chromosomes. The mod353 mutation also affects the size of PsA, a cell surface glycoprotein carrying the modB-dependent O-glycan.
\end{abstract}

\section{Introduction}

The cellular slime mould Dictyostelium discoideum is a simple eukaryote that can exist as unicellular vegetative amoebae, but upon starvation forms aggregates, then a multicellular migratory slug, and later a fruiting body consisting of stalk cells, spores and a small group of basal disc cells (Raper, 1984). As a model system for studies of morphogenesis, $D$. discoideum has the advantage that it has both unicellular and multicellular life stages and can be manipulated genetically. Many monoclonal antibodies (mAbs) raised against $D$. discoideum cells recognize common carbohydrate epitopes on glycoproteins (Murray et al., 1984; Bertholdt et al., 1985; Siu et al., 1985; Alexander et al., 1988; West \& Erdos, 1988).

$D$. discoideum proteins display the recognized posttranslational modifications found in complex eukaryotes, including $\mathrm{N}$-linked and $\mathrm{O}$-linked glycosylation,

† Present address: CSIRO McMaster Laboratory, Sydney University, Sydney, Australia.

$\ddagger$ Present address: Department of Molecular Biology, Princeton University, New Jersey, USA.

$\S$ Present address: Department of Biological Sciences, San Francisco State University, San Francisco, USA.

Abbreviations: mAbs, monoclonal antibodies; i.p., intraperitoneally. inositol-lipid anchors, phosphorylation and sulphation (Glenn \& Williams, 1988). The availability of mutants that carry defects in some of the above post-translational modifications makes this simple eukaryote an excellent system for structural and functional studies of posttranslational processing of proteins.

The lysosomal enzymes of vegetative cells have been the best-studied group of glycoproteins in $D$. discoideum. They contain $\mathrm{N}$-linked sugars termed 'common antigens', identified by a group of $\mathrm{mAbs}$ that have been shown by competitive inhibition to have sulphated or nonsulphated $N$-acetylglucosamine (GlcNAc), or sulphated mannose, as major constituents of their epitopes (Freeze, 1986; Judelson et al., 1987). Many other developmentally regulated glycoantigens have been reported but are less well characterized (Muller \& Gerisch, 1978; Murray et al., 1984; Hohmann et al., 1987; West \& Erdos, 1988; see also Freeze, 1991, for an excellent review of glycosylation in $D$. discoideum). Our research on the migratory slug stage of development has revealed at least two distinct carbohydrates that occur on different 'families' of glycoproteins. These two major glycoprotein families are defined by the presence of epitopes recognized by the previously described mAbs MUD50 and MUD52 which were raised after the injection of slime sheath (extracellular matrix, ECM) into mice (Grant \& Williams, 1983). In 


\section{Table 1. Relevant genotypes of haploid strains referred to in this study}

Phenotypes for mutations at these loci are : acr, resistance to acriflavin [100 $\mu \mathrm{g} \mathrm{ml}^{-1}$ or $2 \%(\mathrm{v} / \mathrm{v})$ in methanol]; bsg, inability to grow using Bacillus subtilis as a food source; $b w n$, formation of brown pigment; cou, sensitivity to $1.3 \mathrm{mM}$-coumarin; $c y c$, resistance to cycloheximide $\left(500 \mu \mathrm{g} \mathrm{ml} \mathrm{l}^{-1}\right.$ ); frt, distribution of fruiting bodies in concentric rings; man, $\alpha$-mannosidase-1-deficient; mat, mating type; mod, glycosylation-defective mutation, loss of either MUD50 or MUD62 epitope; psp, allele of PsA at which the gene product is polymorphic for molecular mass; spr, altered spore shape; tsg, temperature-sensitive for growth; whi, white spores, absence of normal yellow spore pigment. + denotes wild-type (non-mutant) allele. * denotes genotype unconfirmed. Strain designation: HU, haploid; DU, diploid. Diploid DU2981 has parents HU407 and HU2470.

\begin{tabular}{|c|c|c|c|c|c|c|c|c|c|c|c|c|c|c|c|}
\hline $\begin{array}{l}\text { Haploid } \\
\text { strain }\end{array}$ & Parent & acr & bsg & $b w n$ & cou & $c y c$ & frt & $\operatorname{man}$ & mat & $\bmod$ & $p s p$ & $s p r$ & tsg & whi & References \\
\hline HU407 & DU584 & + & $A 5$ & $A I$ & A351 & $A I$ & B353 & $A 2$ & $A I$ & + & A350 & + & $K 21$ & + & Welker \& Williams (1980) \\
\hline HU2460 & DU2974 & + & + & + & A351 & + & B353 & + & A364 & B501 & A353 & + & $K 21$ & + & A. A. Gooley \& K. L. Williams (unpublished) \\
\hline HU2470 & $\mathrm{X} 22$ & $A 1$ & + & + & + & + & + & + & + & -352 & A350 & $A 1$ & $D 12, E 13$ & $A I$ & This study \\
\hline HU2471 & $\mathrm{X} 22$ & $A 1$ & + & + & + & + & + & + & + & -353 & $A 350$ & $A 1$ & $D 12, E 13$ & $A I$ & This study \\
\hline HU2484 & DU2981 & + & * & + & $A 351$ & $A 1$ & $B 353$ & $A 2$ & $A I$ & -352 & A350 & + & $\mathrm{K} 21$ & + & This study \\
\hline WS576 & & + & + & + & + & + & + & + & A364 & + & A353 & + & + & + & Erdos et al. (1973) \\
\hline
\end{tabular}

addition to sheath glycoproteins, these glycoconjugates occur on glycoproteins found primarily, but not exclusively, in prespore cells (Alexander et al., 1988). The carbohydrate antigens recognized by the two mAbs are immunodominant over other $D$. discoideum slug-stage antigens in mice. Two major glycoproteins recognized by $\mathrm{mAb}$ MUD50 are the prespore-specific surface glycoprotein PsA (Grant et al., 1985; Alexander et al., 1988) and the internal prespore glycoprotein PsB (Smith et al., 1989). The epitope recognized by MUD50 is an O-linked carbohydrate, as judged from protein sequence analysis of PsA (A. A. Gooley, unpublished). The use of wild-type slugs as immunogens results in a predominance of mAbs with specificities identifying determinants present on some, but not all, of the MUD50-identified glycoproteins. Strains carrying a mutation in the $\bmod B$ gene lack this type of glycosylation, and therefore do not carry the epitope recognized by this family of mAbs (Alexander $e t$ al., 1988). Here we show that when slugs carrying a modB mutation are used as the immunogen, many of the mAbs produced are specific for a second family of glycoproteins. The definitive $\mathrm{mAb}$ for this group is MUD62 (previously MUD52, Grant \& Williams, 1983). MUD62 identifies a series of glycoproteins in the slime sheath, slug cells and spores, the major antigens in the two latter stages being the spore coat proteins, SP96 and SP75 (see Discussion). We also report our findings on the occurrence and relationships between these two major families of carbohydrates, and introduce two new glycosylationdefective mutant strains which lack the glycoconjugate identified by MUD62.

\section{Methods}

$D$. discoideum culture and strains. Haploid strains of $D$. discoideum are described in Table 1. All strains were grown on a lawn of bacteria
(Klebsiella pneumoniae) on SM agar (Sussman, 1966). The method of slug production has been described by Gregg et al. (1982).

$m A b$ production. Production of mAbs MUD50 and MUD52 (subclone MUD62 is used here) have been described previously (Grant $\&$ Williams, 1983). It is necessary here to clarify the situation with respect to previously published information on MUD52/62. On Western blots of slug antigens, MUD52 was originally found to recognize several glycoproteins including a $30 \mathrm{kDa}$ species (Grant \& Williams, 1983; Grant et al., 1985). It would now appear that this was incorrect, and that the original antibody used may have been contaminated by another antibody, MUD51. The antibody has been redefined after three clonings as MUD62, and is identical to MUD52 in its binding pattern on Western blots of slug antigens, except that MUD62 does not recognize any glycoprotein lower than about $40 \mathrm{kDa}$ on slug cells, and definitely does not recognize the prespore-specific antigen, PsA.

Fusion techniques and conditions for production of new mAbs were similar to those described elsewhere (Goding, 1986). Antigens used for the production of the MUD50-related antibodies were wild-type slugs (strain WS576) either lyophilized in $10 \mathrm{~mm}$-Tris/borate buffer ( $\mathrm{pH} \mathrm{6.5)}$ or fresh in $20 \mathrm{~mm}$-potassium phosphate ( $\mathrm{pH} 6.5$ ). Partially purified membranes of HU2460 (modB50I) slugs in $50 \mathrm{~mm}$-Tris/HCl buffer containing $2 \mathrm{mM}^{-\mathrm{MgSO}_{4}}$ (pH 8.5) were used for the experiments in which MUD62-like mAbs were produced. In both cases 6-week-old female Balb/c mice were used and the volume of the injections was $0.2 \mathrm{ml}$, containing approximately $50 \mu \mathrm{g}$ total protein. An initial injection was given intraperitoneally (i.p.) in Freund's complete adjuvant (CSL), followed by one or more i.p. boosts in Freund's incomplete adjuvant (CSL) prior to fusion with NSl cells in the presence of $35 \%(w / v)$ PEG (Goding, 1986). Hybridomas were screened using a dot immunobinding assay (Smith et al., 1984).

Western blots. Western blotting was used to characterize mAbs. SDSPAGE was used under reducing conditions according to Laemmli (1970) and proteins were electrophoretically transferred to a sheet of nitrocellulose (Schleicher and Schuell, PH79) using a semi-dry method (Khyse-Anderson, 1984). The transfers, either whole or cut into strips, were probed with hybridoma supernatants, and binding was detected with horseradish peroxidase- (HRP) conjugated sheep anti-mouse antibody (Silenus Laboratories), developed with 4-chloronaphthol $\left(0 \cdot 5 \mathrm{mg} \mathrm{ml}^{-1}\right)$ (Sigma).

Flow cytometry. Spores and disaggregated slug cells were analysed for $\mathrm{mAb}$ presence on the cell surface by immunofluorescent labelling with 
a second antibody technique, using fluorescein isothiocyanate- (FITC) conjugated sheep anti-mouse antibody (Silenus Laboratories). Detection was on a Coulter Electronics EPICS V flow cytometer, with an argon-ion laser operating at $488 \mathrm{~nm}$. Methods of sample preparation and the range of machine settings have been reported previously (Alexander et al., 1988 Bernstein et al., 1988). Competition assays between mAbs MUD50 and MUD115, and MUD122 and MUD124 were performed by preincubation of disaggregated slug cells with excess unlabelled antibody $\left(180 \mu \mathrm{l}\right.$ cell culture supernatant $/ 2 \times 10^{5}$ cells) on ice for $35 \mathrm{~min}$ before incubation with FITC-conjugated MUD50 antibody (FM50) and flow cytometry. Preincubation with unlabelled MUD50 and the PsA-peptide-specific mAb MUD1 were used as controls.

Mutagenesis and genetic analysis. Amoebae of strain X22 were mutagenized with $N$-methyl- $N^{\prime}$-nitro- $N$-nitrosoguanidine $(100 \mu \mathrm{g}$ $\mathrm{ml}^{-1}$ ) to $10 \%$ survival as described previously (Kessin et al., 1974). After mutagenesis, amoebae were plated clonally and slugs of individual colonies screened for the loss of MUD50 and/or MUD62 epitopes using dot immunobinding assays (Smith et al., 1984).

Standard parasexual genetic techniques were used to construct diploids (Loomis, 1987). Haploids were obtained on SM agar containing thiabendazole $\left(2 \mu \mathrm{g} \mathrm{ml}^{-1}\right)$, while mitotic crossing over on linkage group II was analysed using methanol $(2 \%$, v/v) SM agar (Welker \& Williams, 1982).

\section{Results}

\section{Immunodominance of the glycoconjugate identified by} MUDSO

In three fusions, using wild-type slugs as immunogens, mAbs recognizing $\bmod B$-sensitive epitopes were dominant. Eight such $\mathrm{mAbs}$ were cloned. These mAbs recognized epitopes shared by many glycoproteins and had Western blot recognition patterns that were similar, but not identical to that of MUD50, as is illustrated in Fig. 1 (tracks D, E-H). In particular, the wellcharacterized glycoproteins PsA and PsB were definitely recognized by these $m A b s$, although the reaction with PsA was weaker with these antibodies than with MUD50. At least three of these mAbs (MUD115, MUD122 and MUD124) behaved similarly to MUD50 in flow cytometry studies in that they identified epitopes on the surface of prespore cells, but not prestalk cells or spores (data not shown). Competition studies between these three mAbs and MUD50 indicated that each of these $\mathrm{mAbs}$ recognizes an epitope different from that bound by MUD50 (Fig. 2). Therefore, at least two separate epitopes on the $\bmod B$-sensitive glycoconjugate are represented in this group of mAbs (Fig. 2).

\section{A second immunodominant glycoconjugate}

A second glycogonjugate, that recognized by antibody MUD62, had also been identified in studies using extracellular matrix from slugs as the immunogen (Grant \& Williams, 1983). This glycoconjugate, a minor antigen

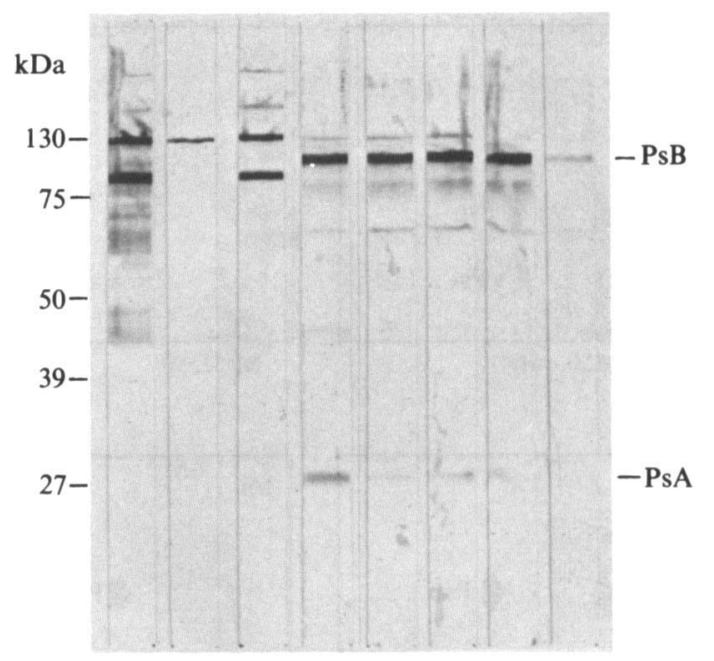

$\begin{array}{llllllll}\text { A } & \text { B } & \text { C } & \text { D } & \text { E } & \text { F } & \text { G } & \text { H }\end{array}$

Fig. 1. Western blots showing recognition of wild-type slug antigens (strain WS380B) by mAbs MUD50 and MUD62, and mAbs raised against wild-type and $\operatorname{modB}$ slug antigens. Tracks: A, MUD62; B, MUD141; C, MUD142; D, MUD50; E, MUD122; F, MUD124; G, MUD109; H, MUD115.

when wild-type slugs were used as the immunogen, became the major antigen recognized by $\mathrm{Balb} / \mathrm{c}$ mice when slug cell membranes of a $\bmod B$ mutant (lacking the MUD50 epitope) were used as the immunogen. In an experiment in which membranes from HU2460 (modB501) slugs were used, 25 out of $52 \mathrm{mAbs}$ had banding patterns identical to MUD62 (Fig. 3). They also behaved similarly to MUD62 in flow cytometry in that they did not bind to the surface of prestalk or prespore cells, but labelled the surface of mature spores (data not shown). MUD62 has been shown to identify internal antigens in prespore cells when digitonin is used to permeabilize slug cells (Bernstein et al., 1988). The remaining $\mathrm{mAbs}$ identified at screening showed three different patterns, two of which will be discussed elsewhere. The third pattern, represented by MUD141, involves recognition of a single band at an apparent molecular mass of $96 \mathrm{kDa}$. This protein is identical in molecular mass to one of the major glycoproteins recognized by MUD62 (Fig. 1, track B), and to that recognized by $m A b$ MUD3, which recognizes the spore coat protein SP96 (West \& Erdos, 1990). The $96 \mathrm{kDa}$ molecule recognized by MUD141, MUD62 and MUD3 is extracted from spores by boiling in $1 \%(\mathrm{w} / \mathrm{v})$ SDS (data not shown), and so it is concluded that all three antibodies identify spore coat glycoprotein SP96.

\section{Mutations which alter the MUD62 glycoconjugate}

In a search for new classes of glycosylation-defective mutants, $4 \times 10^{3}$ colonies of mutagenized X22 cells were 


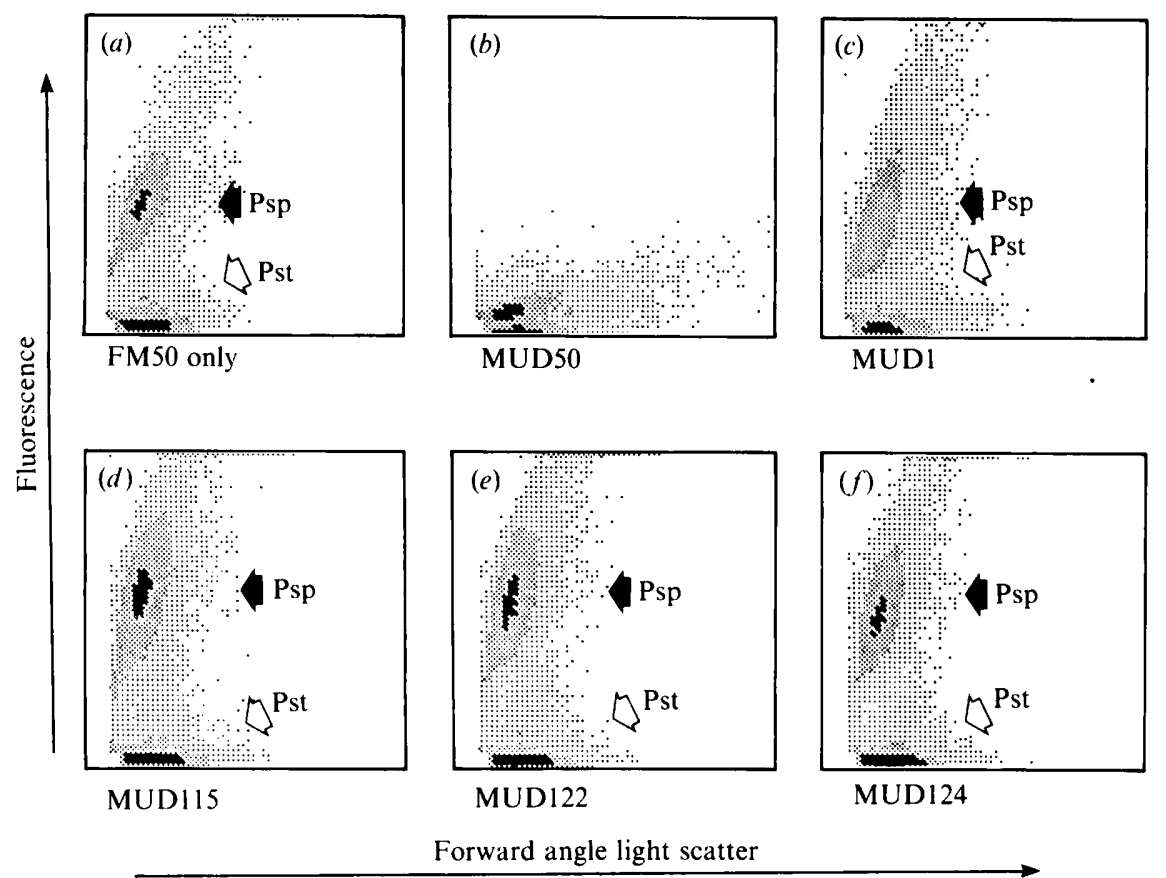

Fig. 2. Competition studies between FITC-conjugated MUD50 antibody (FM50), and unlabelled MUD50-like antibodies using flow cytometry. Disaggregated wild-type slug cells (strain WS380B) were incubated with FM50 only $(a)$, or first incubated with an excess of unlabelled antibody, then with FM50. Unlabelled antibodies used were: (b) MUD50, (c) MUD1, (d) MUD115, (e) MUD122, (f) MUD124. Psp, prespore cells, Pst, prestalk cells.

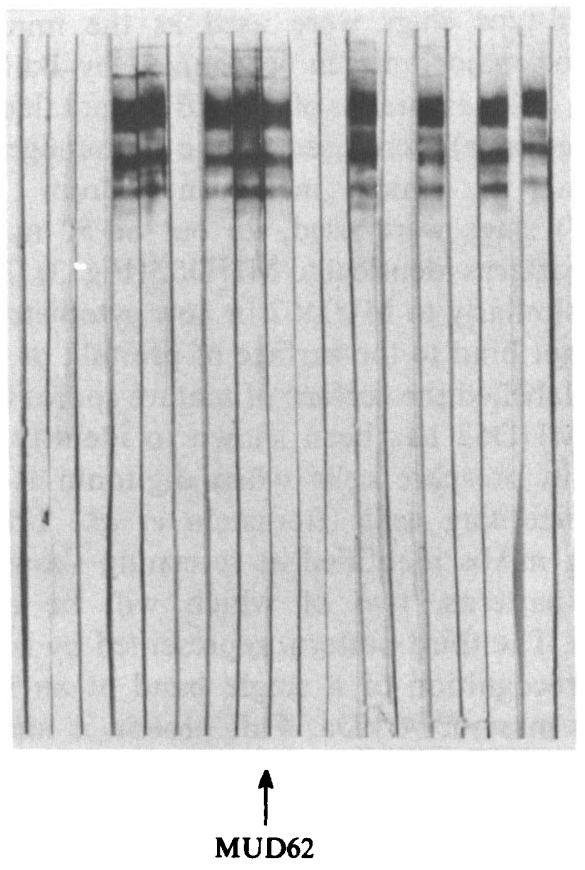

Fig. 3. Strip Western blot screening of a cell fusion showing a typically high proportion of mAbs recognizing epitopes similar in pattern to MUD62 (marked). The antigen used for this fusion was a crude membrane preparation of modB slug cells (strain HU2460).

screened for the absence of the MUD50 and MUD62 epitopes. Two strains, HU2470 (mod-352) and HU2471 (mod-353) were found to lack the MUD62 epitope, but still retained the MUD50 epitope. Both of these strains developed normally, producing viable spores, although their aggregation was somewhat delayed and HU2471 produced slightly smaller colonies than its parent X22.

Strains HU2470 and HU2471 were crossed to the wellmarked tester strain HU407, and in both cases the resulting diploids (DU2981 and DU2997, respectively) were wild-type for the MUD62 epitope. Hence, both the mod-352 and mod-353 mutations are recessive to wildtype. Segregation of DU2997 showed that the mod-353 mutation mapped to linkage group II (Table 2) as cosegregation was observed between the acrAl, whiAl and mod-353 alleles, and markers on linkage groups I, III, IV, VI, and VII segregated independently. [Linkage group I produced skewed segregation in that 24 of 26 segregants were cycloheximide-resistant and therefore carried the HU407 linkage group I ( $c y c A l)$. This was not unexpected as linkage group I of strain X22, the parent of HU2471, carries a mutation that leads to increased sensitivity to thiabendazole, the agent used to haploidize the diploid (K. L. Williams, unpublished)].

Confirmation that the mod-353 gene maps to linkage group II was obtained by mitotic crossing-over based on selection of diploids homozygous at acrAl. One whitespored diploid and three yellow-spored diploids (all growth temperature-sensitive) were obtained, all of which were homozygous for the mod-353 mutation. This result is consistent with the mod-353 gene being distal to the acrA locus (Welker \& Williams, 1982).

Haploid strain HU2484 was obtained from segregation of diploid DU2981 (HU2470 $\times$ HU407) as a mod$352, t s g K 21$ strain which did not carry the $t s g D 12$ and tsgE 13 mutations present in strain HU2470. This made it 


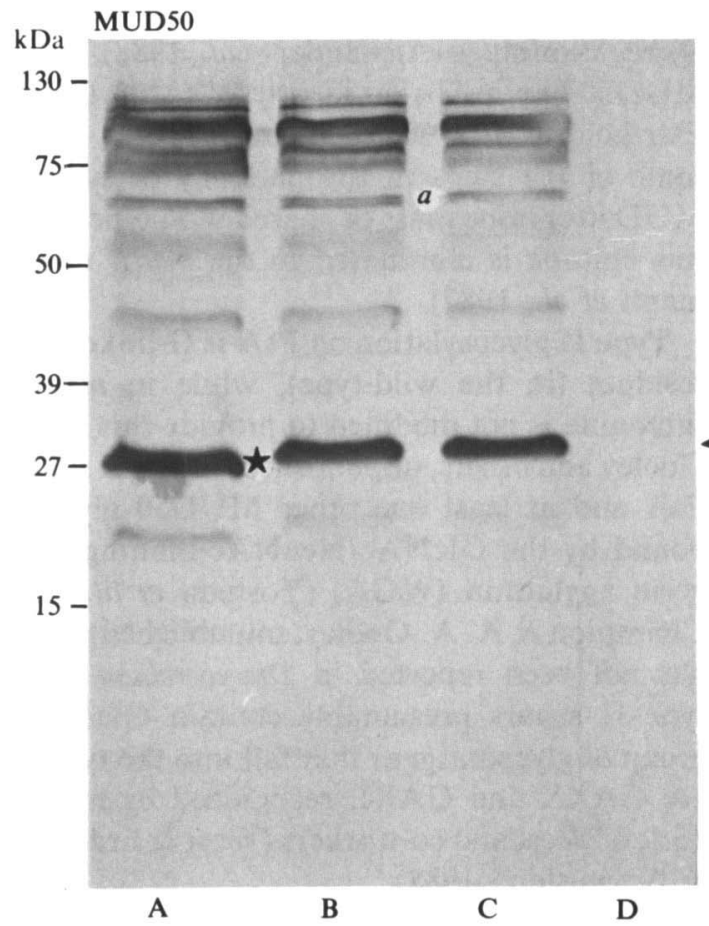

(a)

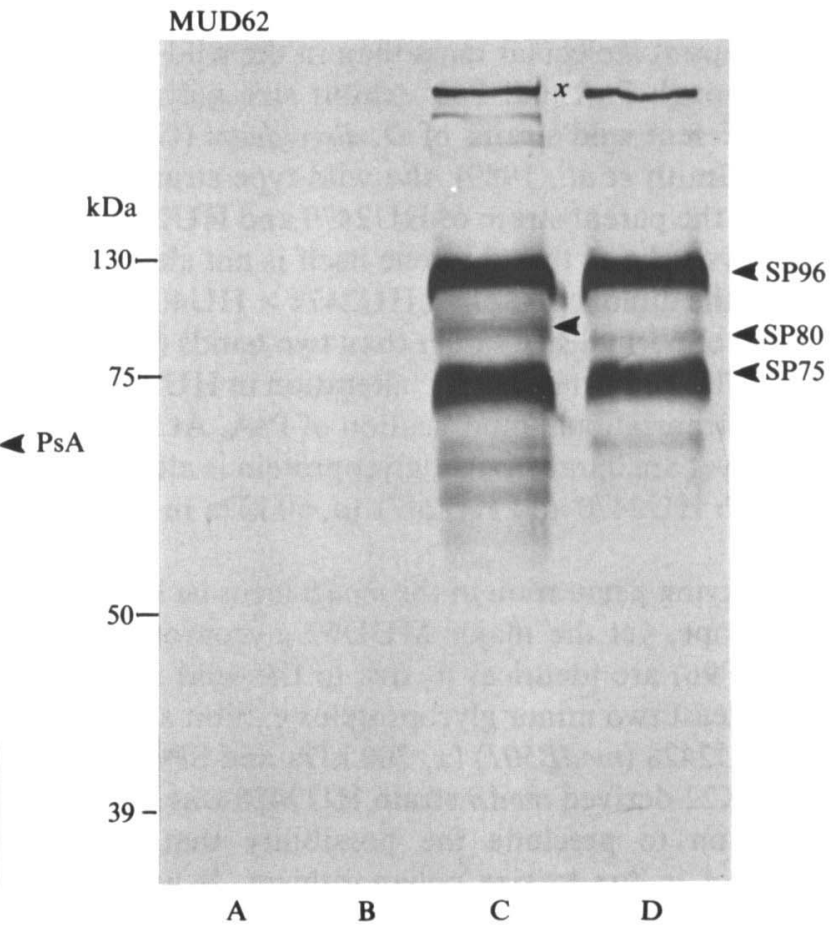

(b)

Fig. 4. Western blot of wild-type and mutant $D$. discoideum slug proteins probed with mAbs MUD50 and MUD62. The MUD50 gel is $12 \%(\mathrm{w} / \mathrm{v}$ ) acrylamide; the MUD62 gel is 7.5\%. Tracks: A, strain HU2471 (mod-353); B, strain HU2470 (mod-352); C, strain X22 (wildtype parent strain); D, strain HU2428 (modB501). Note the small molecular mass decrease in PsA in strain HU2471 ( $\star$ ) ), and in glycoproteins $a$ (HU2471 and HU2470), $x$ and SP80 (HU2428).

Table 2. Linkage analysis of 26 haploid segregants of diploid DU2997, which is heterozygous for the mod-353 mutation

\begin{tabular}{|c|c|c|c|c|c|c|c|c|c|c|c|c|c|c|}
\hline \multirow[b]{3}{*}{$\begin{array}{c}\text { Diploid } \\
\text { (parental haploids) }\end{array}$} & \multirow[b]{3}{*}{$\underset{\text { genotype }}{\bmod }$} & \multirow[b]{3}{*}{$\begin{array}{l}\text { No. of } \\
\text { segregants }\end{array}$} & \multicolumn{12}{|c|}{ No. of segregants in linkage group: } \\
\hline & & & \multicolumn{2}{|r|}{ I } & \multicolumn{2}{|r|}{ II } & \multicolumn{2}{|c|}{ III } & \multicolumn{2}{|c|}{ IV } & \multicolumn{2}{|r|}{ VI } & \multicolumn{2}{|r|}{ VII } \\
\hline & & & + & $\operatorname{cycAl}$ & + & whiAl & + & $b s g A 5$ & + & bwnA5 & + & $\operatorname{man} A 2$ & + & $\begin{array}{l}\text { tsgK21 } \\
\text { couA351 }\end{array}$ \\
\hline $\begin{array}{l}\text { DU2997 } \\
\text { (HU2471, HU407) }\end{array}$ & $\begin{array}{c}\bmod -353 \\
+\end{array}$ & $\begin{array}{r}18 \\
8\end{array}$ & $\begin{array}{l}1 \\
1\end{array}$ & $\begin{array}{r}17 \\
7\end{array}$ & $\begin{array}{l}0 \\
8\end{array}$ & $\begin{array}{r}18 \\
0\end{array}$ & $\begin{array}{l}9 \\
4\end{array}$ & $\begin{array}{l}9 \\
4\end{array}$ & $\begin{array}{r}12 \\
5\end{array}$ & $\begin{array}{l}6 \\
3\end{array}$ & $\begin{array}{l}9 \\
4\end{array}$ & $\begin{array}{l}9 \\
4\end{array}$ & $\begin{array}{r}11 \\
7\end{array}$ & $\begin{array}{l}7 \\
1\end{array}$ \\
\hline
\end{tabular}

possible to cross HU2484 with HU2471 and therefore test for complementation between mod-352 (HU2484) and mod-353 (HU2471). Diploid strain DU2995 (HU2471, HU2484; mod-353 +/+ mod-352) expressed the MUD62 epitope. Therefore, mutations mod-352 and mod-353 affect different genes. Segregation of DU2995 on SM agar containing thiabendazole $\left(2 \mu \mathrm{g} \mathrm{ml}^{-1}\right)$ resulted in 28 of 68 haploid segregants being wild-type for MUD62. Therefore, mod-352 and mod-353 are unlinked.

Preliminary mapping experiments using diploid DU2981 (HU407 $\times$ HU2470) confirmed that mod-352 is not on linkage group I, II, VI or VII and it has thus been tentatively mapped to either linkage group III or IV.

\section{MUD62- and MUD50-related glycosylation mutations affect the size of other glycoconjugates}

The results of Western blots indicate that the glycoconjugates recognized by the mAbs MUD50 and MUD62 occur on different glycoproteins (Fig. 4). Certainly, no major readily identifiable molecule is recognized by both mAbs, with the possible exception of SP80, which is discussed below.

Western blots of slug proteins from strains HU2470 (mod-352) and HU2471 (mod-353) do not have the epitopes recognized by MUD62, but when probed with MUD50 the normal pattern of glycoproteins is apparent 
(Fig. 4). However, in HU2471 (but not HU2470) PsA has a smaller apparent molecular mass than in the wild-type (Fig. 4). Although PsA and PsB exhibit size polymorphisms in different wild strains of $D$. discoideum (Grant et al., 1985; Smith et al., 1989), the wild-type strain in Fig. 4 is X22, the parent strain of HU2470 and HU2471. Genetic analysis shows that the gene itself is not altered since PsA in the diploid DU2997 (HU2471 $\times$ HU407) is a single band of normal size rather than two bands (data not shown). This indicates that the alteration in HU2471 is in the post-translational modification of PsA. At least one other, as yet uncharacterized, glycoprotein is altered in size in both HU2470 and HU2471 ( $a, 60 \mathrm{kDa}$ in Fig. 4).

Strains carrying a mutation in the $\bmod B$ locus lack the MUD50 epitope, yet the major MUD62 glycoproteins (SP75 and SP96) are identical in size to the wild-type. However, at least two minor glycoproteins exhibit a size change in HU2428 $(\operatorname{modB} 501)(x, 200 \mathrm{kDa}$ and SP80 in Fig. 4). The X22-derived $\bmod B$ strain HU2428 was used for comparison to preclude the possibility that the observed effect is due to size polymorphism. It would appear that the $80 \mathrm{kDa}$ species is SP80, another spore coat protein, which is reported to show a molecular mass change in modB strains (Aparicio et al., 1990). SP80 may carry both epitopes, but other explanations are possible.

\section{Discussion}

The co- and post-translational modification of proteins is now recognized to be of major structural and functional importance, and considerable interest is being shown in the pathways of glycosylation and the functions and antigenicity of the sugars (see reviews by Feizi \& Childs, 1987; Kornfeld \& Kornfeld, 1985; West, 1986; Hart et al., 1988; Freeze, 1991).

In $D$. discoideum, previous studies have identified several types of glycosylation, the best-studied being the $\mathrm{N}$-linked glycosylation of lysosomal enzymes of vegetative cells (Freeze, 1986) and the type I (N-linked) and type II (modB-dependent) glycosylation of the glycoprotein contact site A (CsA), which appears during the aggregation stage (Hohmann et al., 1985, 1987). Our studies concentrate on glycoproteins present at a later developmental stage, the tissue-like multicellular slug, although time courses of development and other studies show that both MUD62 and MUD50 recognize glycoproteins in earlier (vegetative amoebae and aggregate) and later (fruiting body) stages. The reported types of post-translational modification can now be classified in terms of what is known about their processing and structure.

The MUD50 epitope is not present on CsA, as
MUD50 does not label the surface of cells at the aggregation stage (Alexander et al., 1988), although other MUD50-like mAbs do identify CsA on the cell surface (Bertholdt et al., 1985; Bozzaro \& Merkl, 1985). At least some of the steps in the pathway of synthesis of the MUD50 epitope must be shared with type II sugars since this epitope is eliminated in the $\bmod B$ mutants (Hohmann et al., 1987).

Type II glycosylation on PsA is O-linked to threonine residues (in the wild-type), while in $\bmod B$ mutants, threonine is not modified to provide this linkage (A. A. Gooley and others, unpublished). Type II sugars on CsA, PsA and at least one other MUD50 glycoprotein are bound by the GlcNAc/NeuNAc-binding lectin, wheat germ agglutinin (WGA) (Yoshida et al., 1984; A. C. Champion \& A. A. Gooley, unpublished). As sialic acid has not been reported in Dictyostelium glycoproteins, type II sugars presumably contain GlcNAc. Another group of glycoantigens that fall into the type II category are GAXX and GAXI, recognized by mAbs 54.2 and 16.1, of West and co-workers (West \& Erdos, 1988; West \& Brownstein, 1988).

The MUD62 glycoconjugate is also O-linked (K. L: Williams \& M. R. Wilkins, unpublished) but it is still present in strains carrying the $\bmod B$ mutation, and is therefore processed via a different pathway, although some sugars may be common. The two new mutations described here, mod-352 and mod-353, define this new pathway of O-linked glycosylation, and do not prevent type II (modB-dependent) glycosylation. Antibody recognition studies (Western blots) using strains HU2470 (mod-352), HU2471 (mod-353) and a further mutant, HL250 (Gonzalez-Yanes et al., 1989), indicate that the MUD62 glycoantigen is similar to that recognized by mAb 83.5 of West and co-workers (C. M. West, personal communication). This glycoantigen is named GA-X, and is reported to be an O-linked GlcNAc-containing oligosaccharide (Gonzalez-Yanes et al., 1989). mAb 83.5 recognizes a fucose epitope on GA-X, which is present on spore coat proteins designated by Gonzalez-Yanes $e t$ al. (1989) as SP75, SP80 and SP96. This epitope is confined in aggregates and slugs to prespore vesicles in prespore cells (West \& Erdos, 1988; Gonzalez-Yanes et al., 1989). MUD62 recognizes major glycoproteins with apparent molecular mass of 75, 80 and $96 \mathrm{kDa}$ (Fig. 4). The 75 and $96 \mathrm{kDa}$ species bind the $\alpha$-fucose-binding lectin Anguilla anguilla agglutinin (AAA) (A. C. Champion \& A. A. Gooley, unpublished). The $80 \mathrm{kDa}$ species exhibits a decrease in apparent molecular mass in $\bmod B$ strains, as has been reported for the spore coat protein SP80 (Aparicio et al., 1990). It is therefore likely that MUD62 recognizes a sugar moiety present on the same GA-X proteins (spore coat proteins SP75, SP80 and SP96), recognized by $\mathrm{mAb} 83.5$. The MUD62 epitope is 
present in, but not exclusive to, prespore vesicles in aggregates and slugs (M. Fuchs, unpublished); however the MUD62-related antibody MUD142 (Fig. 1) is specifically confined to the prespore vesicles in slug cells (M. Fuchs, unpublished) and therefore may be identical to mAb 83.5.

MUD50 and MUD62 were raised as antibodies to sheath (extracellular matrix) glycoproteins (Grant \& Williams, 1983; Grant et al., 1985). Both MUD50 and MUD62 recognize patterns of glycoproteins on Western blots of sheath proteins that differ from slug proteins. Although there are common glycoproteins which may be due to contaminating cells left in the trail, at least some of each family of glycosylated proteins are secreted by the slug to form part of the extracellular matrix. These glycoproteins are essentially undetectable in slug cells (Grant \& Williams, 1983; Alexander et al., 1988). Evidence is mounting that glycoproteins that carry the modB-dependent glycosylation have a role in slug traction (Vardy et al., 1986; Breen et al., 1987; Breen \& Williams, 1988). The mod-352/mod-353-dependent glycosylation occurs on a different group of extracellular matrix proteins that may have a role in lubrication of slug movement, as determined by immunofluorescence microscopy of intact trails (Breen \& Williams, 1988). Further investigation of strains carrying combinations of the $\bmod B, \bmod -352$ and $\bmod -353$ mutations using mAbs and lectins should help elucidate the nature of the mutations, and eventually the structure and function of the glycosylation.

This work was supported by an Australian Research Council Program grant to K.L.W., an ARC grant to E.S., and NH\&MRC grant 890627 to K.L.W. and J. Redmond, School of Chemistry, Macquarie University. We thank Chris West for exchange of information prior to publication.

\section{References}

AleXander, S., Smith, E., Davis, L., Gooley, A., Por, S. B., Browne, L. \& WiLliaMs, K. L. (1988). Characterization of an antigenically related family of cell-type specific proteins implicated in slug migration in Dictyostelium discoideum. Differentiation 38, 82-90.

Aparicio, J. G., ERDos, G. W. \& WeSt, C. M. (1990). The spore coat is altered in modB glycosylation mutants of Dictyostelium discoideum. Journal of Cellular Biochemisty 42, 255-266.

Bernstein, R. L., Browne, L. H., Yu, S. C. \& Williams, K. L. (1988). Detergent treatment of Dictyostelium discoideum cells allows examination of internal cell type specific antigens by flow cytometry. Cytometry 9, 68-74.

Bertholdt, B. G., Stadtler, J., Bozzaro, S., Fitchner, B. \& GERISCH, G. (1985). Carbohydrate and other epitopes of the contact site A glycoprotein of Dictyostelium discoideum as characterized by monoclonal antibodies. Cellular Differentiation 16, 187-202.

Bozzaro, S. \& MERKL, R. (1985). Monoclonal antibodies against Dictyostelium plasma membranes: their binding to simple sugars. Cellular Differentiation 17, 83-94.

BREen, E. J. \& Williams, K. L. (1988). Movement of the Dictyostelium discoideum slug: models, musings and images. Developmental Genetics 9, 539-548.
Breen, E. J., Vardy, P. H. \& Williams, K. L. (1987). Movement of the multicellular slug stage of Dictyostelium discoideum: an analytical approach. Development 101, 313-321.

ERDOS, G. W., RAPER, K. B. \& VoGEN, L. K. (1973). Mating types and macrocyst formation in Dictyostelium discoideum. Proceedings of the National Academy of Sciences of the United States of America 70, 1828-1830.

FeIzI, T. \& ChILDS, R. A. (1987). Carbohydrates as antigenic determinants of glycoproteins. Biochemical Journal 245, 1-11.

FREEZE, H. H. (1986). Modifications of lysosomal enzymes in Dictyostelium discoideum. Molecular and Cellular Biochemistry 72, 4765.

FREEZE, H. H. (1991). Developmental glycobiology of Dictyostelium discoideum. In Cell Surface Carbohydrates and Cell Development. Edited by M. Fukuda. Boca Raton: CRC Press.

GlenN, D. \& Williams, K. L. (1988). Dictyostelium discoideum: its future in biotechnology. Australian Journal of Biotechnology, 4651 .

Goding, J. W. (1986). Monoclonal Antibodies: Principles and Practice, 2nd edn. London: Academic Press.

Gonzalez-Yanes, B., Mandell, R. B., GiraRd, S. H., Aparicio, O., Gritzali, M., Brown, R. D., Erdos, G. W. \& WeSt, C. M. (1989). The spore coat of a fucosylation mutant in Dictyostelium discoideum. Developmental Biology 133, 576-587.

Grant, W. N. \& Williams, K. L. (1983). Monoclonal antibody characterisation of slime sheath: the extra-cellular matrix of Dictyostelium discoideum. EMBO Journal 2, 935-940.

Grant, W. N., Welker, D. L. \& Williams, K. L. (1985). A polymorphic, prespore specific cell surface glycoprotein is present in the extracellular matrix of Dictyostelium discoideum. Molecular and Cellular Biology 5, 2559-2566.

Gregg, J. M., Krefft, M., Haas-Kraus, A. \& Williams, K. L. (1982). Antigenic differences between prespore cells of Dictyostelium discoideum and Dictyostelium mucoroides using monoclonal antibodies. Experimental Cell Research 142, 229-233.

HART, G. W., HolT, G. D. \& HalTiwanger, R. S. (1988). Nuclear and cytoplasmic glycosylation: novel saccharide linkages in unexpected places. Trends in Biochemical Sciences 13, 380-384.

Hohmann, H.-P., Gerisch, G., Lee, R. W. H. \& HuttNer, W. B. (1985). Cell-free sulphation of the contact site A glycoprotein of Dictyostelium discoideum and of a partially glycosylated precursor. Journal of Biological Chemistry 260, 13869-13878.

Hohmann, H.-P., Bozzaro, S., Merki, R., Wallraff, E., Yoshida, M., WeinharT, U. \& Gerisch, G. (1987). Post-translational glycosylation of the contact site A protein of Dictyostelium discoideum is important for stability but not for its function in cell adhesion. EMBO Journal 6, 3663-3671.

Judelson, H. S., Freeze, H. H. \& Dimond, R. L. (1987). Characterisation and distribution of multiple antigens on $\mathrm{N}$-linked oligosaccharides of Dictyostelium discoideum proteins. Archives of Biochemistry and Biophysics 253, 305-314.

Kessin, R. H., Williams, K. L. \& Newell, P. C. (1974). Linkage analysis in Dictyostelium discoideum using temperature sensitive growth mutants selected with bromodeoxyuridine. Journal of Bacteriology 119, 776-783.

KHYSE-ANDERSON, J. (1984). Electroblotting of multiple gels: a simple apparatus without buffer tank for rapid transfer of protein from polyacrylamide to nitrocellulose. Journal of Biochemical and Biophysical Methods 10, 203-209.

KORNFELD, R. \& KORNFELD, S. (1985). Assembly of asparagine-linked oligosaccharides. Annual Review of Biochemistry 54, 631-654.

LAEMMLI, U. K. (1970). Cleavage of structural proteins during the assembly of the head of bacteriophage T4. Nature, London 227, 680685.

LoOMis, W. F. (1987). Genetic tools for Dictyostelium discoideum. Methods in Cell Biology 28, 31-65.

MULLER, K. \& GERISCH, G. (1978). A specific glycoprotein as the target site of adhesion blocking Fab in aggregating Dictyostelium cells. Nature, London 274, 445-449.

MurRay, B. A., Wheeler, S., Jongens, T. \& LoOMIS, W. F. (1984). Mutations affecting a surface glycoprotein, gp80, of Dictyostelium discoideum. Molecular and Cellular Biology 4, 514-519. 
RAPER, K. B. (1984). The Dictyostelids. New Jersey: Princeton University Press.

SiU, C.-H., LAM, T. Y. \& CHOI, H. C. (1985). Inhibition of cell-cell binding at the aggregation stage of Dictyostelium discoideum development by monoclonal antibodies directed against an 80000 dalton surface glycoprotein. Journal of Biological Chemistry 260, 16030-16036.

Smith, E., Roberts, K., Butcher, G. W. \& Galfre, G. (1984). Monoclonal antibody screening: two methods using antigens immobilised on nitrocellulose. Analytical Biochemistry 138, 119-124.

Smith, E., Gooley, A. A., Hudson, G. C. \& Williams, K. L. (1989). Glycoproteins that exhibit extensive polymorphisms in Dictyostelium discoideum. Genetics 122, 59-64.

SUSSMAN, M. (1966). Biochemical and genetic methods in the study of cellular slime mould development. Methods in Cell Physiology 2, 397410.

Vardy, P. H., Fisher, L. R., Smith, E. \& Williams, K. L. (1986). Traction proteins in the extracellular matrix of Dictyostelium discoideum slugs. Nature, London 320, 526-529.

WELKER, D. L \& WiLLIAMS, K. L. (1980). The assignment of four new loci, including the coumarin sensitivity locus, $\operatorname{couA}$, to linkage group VII of Dictyostelium discoideum. Journal of General Microbiology 120, 149-159.
Welker, D. L. \& Williams, K. L. (1982). A genetic map of Dictyostelium discoideum based on mitotic recombination. Genetics 102, 691-710

WEST, C. (1986). Current ideas on the significance of protein glycosylation. Molecular and Cellular Biochemistry 72, 3-20.

WeST, C. M. \& Brownstein, S. A. (1988). EDTA treatment alters protein glycosylation in the cellular slime mould Dictyostelium discoideum. Experimental Cell Research 175, 26-36.

WEST, C. M. \& ERDOS, G. W. (1988). The expression of glycoproteins in the extracellular matrix of the cellular slime mould Dictyostelium discoideum. Cell Differentiation 23, 1-16.

WEST, C. M. \& ERDOS, G. W. (1990). Formation of the Dictyostelium spore coat. Developmental Genetics 11, 492-506.

Williams, K. L. \& Newell, P. C. (1976). A genetic study of aggregation in the cellular slime mould Dictyostelium discoideum using complementation analysis. Genetics 82, 287-307.

Yoshida, M., Stadler, J., Bertholdt, G. \& Gerisch, G. (1984). Wheatgerm agglutinin binds to the contact site A glycoprotein of Dictyostelium discoideum and inhibits EDTA-stable cell adhesion. EMBO Journal 3, 2663-2670. 